\title{
Post-implementation evaluation and challenges of Integrated Financial Management Information Systems for municipalities in South Africa
}

\begin{tabular}{|c|c|}
\hline \multicolumn{2}{|c|}{$\begin{array}{l}\text { Authors: } \\
\text { Nozibele Gcora }{ }^{1} \text { @ } \\
\text { Wallace Chigona }^{1} \text { (1) }\end{array}$} \\
\hline \multicolumn{2}{|c|}{$\begin{array}{l}\text { Affiliations: } \\
{ }^{1} \text { Department of Information } \\
\text { Systems, Faculty of } \\
\text { Commerce, University of } \\
\text { Cape Town, Cape Town, } \\
\text { South Africa }\end{array}$} \\
\hline \multicolumn{2}{|c|}{$\begin{array}{l}\text { Corresponding author: } \\
\text { Nozibele Gcora, } \\
\text { gcoranozibele@gmail.com }\end{array}$} \\
\hline \multicolumn{2}{|c|}{$\begin{array}{l}\text { Dates: } \\
\text { Received: } 22 \text { Dec. } 2018 \\
\text { Accepted: } 05 \text { July } 2019 \\
\text { Published: } 20 \text { Nov. } 2019\end{array}$} \\
\hline \multicolumn{2}{|c|}{$\begin{array}{l}\text { How to cite this article: } \\
\text { Gcora, N. \& Chigona, W., } \\
\text { 2019, 'Post-implementation } \\
\text { evaluation and challenges of } \\
\text { Integrated Financial } \\
\text { Management Information } \\
\text { Systems for municipalities in } \\
\text { South Africa', South African } \\
\text { Journal of Information } \\
\text { Management 21(1), a1066. } \\
\text { https://doi.org/10.4102/ } \\
\text { sajim.v21i1.1066 }\end{array}$} \\
\hline \multicolumn{2}{|c|}{$\begin{array}{l}\text { Copyright: } \\
\text { (c) 2019. The Authors. } \\
\text { Licensee: AOSIS. This work } \\
\text { is licensed under the } \\
\text { Creative Commons } \\
\text { Attribution License. }\end{array}$} \\
\hline \multicolumn{2}{|c|}{ Read online: } \\
\hline 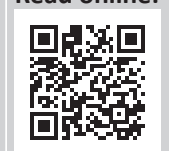 & $\begin{array}{l}\text { Scan this QR } \\
\text { code with your } \\
\text { smart phone or } \\
\text { mobile device } \\
\text { to read online. }\end{array}$ \\
\hline
\end{tabular}

Background: Municipalities in South Africa are currently grappling with the introduction of Integrated Financial Management Information Systems (IFMIS) to improve financial management. Integrated Financial Management Information Systems have been found to be an important tool for economic growth and development by ensuring that municipalities have appropriate management of public resources with the goal of enhancing service delivery to the citizens. Integrated Financial Management Information Systems have been introduced in municipalities in South Africa; however, they have not widespread been used. Previous research mentions wide-range bottlenecks for the acceptance of new technology in government departments, among which are insufficient attention to change management process and acceptance by intended end-users.

Objective: This research study focused on the post-implementation evaluation of IFMIS in municipalities, as well as challenges affecting the implementation of IFMIS. The aim was to establish areas of improvement in the implementation of IFMIS.

Method: Three stages (unfreezing, change and refreezing) and eight steps for successful change management were used as theoretical background to investigate this study. The study employed a qualitative approach and case study research strategy underpinned by the interpretivist philosophical paradigm. The study was performed in five municipalities of the Western Cape province, Republic of South Africa. Interviews were conducted using 16 end-users who were assigned to use IFMIS for work purposes; and specifically, three end-users were interviewed in each of the five municipalities. Deductive thematic analysis was used to analyse the factors affecting change management in the implementation of IFMIS.

Results: Findings show that the implementation of IFMIS in municipalities was a top-down approach that encompasses a linear process where systems were implemented by external vendors, and then introduced to end-users afterwards. The study revealed that end-users were not involved in the implementation, and also that there are challenges affecting system use because of non-involvement of end-users during system implementation.

Conclusion: Implementation should be a user-oriented process, thus resulting in resistance to systems use. End-users should be part of the implementation process and their recommendations should be incorporated in the implementation process because people are more likely to accept the forthcoming change if they know what to expect.

Keywords: Integrated Financial Management Information Systems; IFMIS; postimplementation; change management; municipalities; end-users.

\section{Introduction and background of the study}

The advances in information and communication technologies (ICTs) have changed the way government departments conduct their business (Zakaria, Rahman \& Elsayed 2011). The capabilities of this advancement have led to the introduction of various information systems (IS) in government spheres (DPLG 2010; Lodge 2005). In addition, government departments in developing countries are increasingly exploring methods and systems to modernise and improve public financial management (Micheni 2017). This follows a growing interest in the quality of public sector financial management in developing countries by the donor community (Micheni 2017). Specifically, good financial management is a vital aspect for the public sector, as it can enable an accurate and complete assessment of the impact of policy decisions and aid internal decisions on resources allocation (planning and budgeting), monitoring and accountability 
(Chado 2015; Harelimana 2017; Nabe 2016). In the early years after the fall of the Berlin Wall in 1989, interest in state affairs was limited but, following the World Bank's report, the role of the public sector became increasingly prominent in development efforts, particularly in the drive against service delivery and poverty alleviation (Sulla \& Zikhali 2018). As a result, consultants and other advisors of governments in developing continents such as Africa started brainstorming, with the idea of the introduction of modern IS for financial management such as the Integrated Financial Management Information Systems (IFMIS) (Kiarie \& Wanyoike 2016).

The scope and functionality of IFMIS vary across countries, but, normally, it represents an enormous, complex, strategic reform process for financial management (Selfano, Peninah \& Sarah 2014). Integrated Financial Management Information Systems have been found to be an important tool for economic growth and development by ensuring that government in all its spheres is able to mobilise revenue, manage and safeguard appropriately public resources in a proper and efficient way, with the goal of enhancing service delivery to the citizens (Harelimana 2017; Kiarie \& Wanyoike 2016).

The government of the Republic of South Africa has for a long time been very concerned about the persistent poor performance in financial management because of lack of reliable and timely information for decision-making on its all levels of government, that is, national, provincial and local (National Treasury 2018). Furthermore, specifically, the South African government has for a long time been deeply concerned about local government because of the persistent poor performance in financial management and the lack of reliable and timely information for decision-making (Nabe 2016). In addition, the audit report issued by the AuditorGeneral of South Africa (AGSA) added that improving financial management in government departments should be an important first step to take to increase the efficiency and effectiveness of government service delivery (Ngoepe \& Ngulube 2016). Subsequently, a review by AGSA, financial management, accounting systems and role of audits revealed weaknesses in the management of financial information in local government (Ngoepe \& Ngulube 2016). The review focused on the need to develop a strategic plan aimed at improving the financial management system, skills and capacity within the government financial operations units. It also reviewed how timeliness of financial information, if improved, could form the basis for improving control of expenditure out of the budget of the country (National Treasury 2018).

Local government (municipalities) in South Africa is currently grappling with the introduction of IFMIS as a tool, through which financial management is achieved and can be improved (Da Cruz et al. 2016). National Treasury introduced legislation, relating to the chart of accounts, for all municipalities to implement and integrate their IFMIS based on the Municipal Regulations on a Standard Chart of Accounts (mSCOA) (National Treasury 2018). This means that all municipalities in all provinces of South Africa are required to have financial IS that are configured to operate according to the standards sets for the mSCOA chart by the Treasury of South Africa (National Treasury 2018). Generally, the IFMIS for local government (municipalities) refer to the ICTs in financial operations to support management and budget decisions, fiduciary responsibilities and the preparations of financial reports and statements in the municipalities in South Africa (National Treasury 2018; Ngoepe \& Ngulube 2016).

However, although IFMIS has been introduced in municipalities, only a few of the implementations have reached widespread adoption and, in other municipalities, implementation. There are complexities in the implementation and use of the IFMIS in municipalities (National Treasury 2018). Some authors (Hendricks 2012; Nabe 2016) mention wide-ranging bottlenecks for the acceptance of new technology in local government departments in South Africa, among which are insufficient attention to change management techniques and acceptance by intended endusers. Information systems implementation needs to have a clear change management process in place to ensure a high rate of success; local government is still struggling in this regard (King, Hogkins \& Cornish 2017). Most of IS implementation in the public sector that has failed often has followed a top-down instead of bottom-up approach (Nabe 2016). Top-down implementation of IS in the sector follows a high level of planning by the top management with approved vendors to implement IS for intended end-users (employees) (Ngoepe \& Ngulube 2016). This study investigates the research question: What are the factors and challenges affecting post-implementation of IFMIS for municipalities in South Africa?

It is crucial to first understand the context of municipalities in South Africa and to have a brief understanding as to why change efforts often fail. Stage models of change management by Kotter (1995) and Lewins (1947) were used to theoretically underpin the article. The study employed a qualitative approach based on an interpretivist paradigm to carry out the research. The study was carried out in the Western Cape province of South Africa because this province has already embarked on the implementation of IFMIS based on the mSCOA chart for municipalities. It is envisaged that other provinces may benefit from the lessons learned. The data for the study were collected through semi-structured interviews with intended end-users of IFMIS.

\section{Context and literature review}

\section{The local government (municipalities) in South Africa}

The institutional framework of government in South Africa was established in 1996 with the adoption of the first democratic constitution. It consists of three tiers or spheres national, provincial and local - each with distinctive functional responsibilities (DPLG 2010; Zulu 2014). Local government is charged with a range of roles and 
responsibilities, as set out in the Municipal Systems Act No. 32 of 2000 (DPLG 2010). In the context of the government sector, more especially in South African local government (municipalities), change management is seen as a complex issue (Lodge 2005; Zulu 2014). This is because the local government sphere, compared to the national and provincial government spheres, has complex structures that are embedded in each other (Municipal Demarcation Board 2016; Pasquini et al. 2015). The South African local government sphere is comprised based on Section 151 of the Constitution (Municipal Demarcation Board 2016) as follows:

- Section 151(1): The local sphere of government consists of municipalities, which must be established for the whole territory of the Republic of South Africa.

- Section 151(2): The executive and legislative authority of a municipality is vested in its Municipal Council.

- Section 151(3): A municipality has the right to govern, on its own initiative, the local government affairs of its community, subject to national and provincial legislation, as provided for in the Constitution.

- Section 151(4): The national and provincial may not compromise or impede municipality's ability or right to execute its powers or reform its functions.

Section 152 (2) of the Constitution states that 'A municipality must strive, within its financial and administrative capacity, to achieve the objects set out in subsection 151(1)' (Nabe 2016; Pasquini et al. 2015; Zulu 2014). The local government of South Africa consists of 284 municipalities (DPLG 2010). There are three types of government municipalities in South Africa (as set out in the local government: Municipal Structures Act No. 117 of 1998) in Table 1.

Distinction is made between 'metros and district municipalities' according to the list, names and numbering system used by the Demarcation Board (Municipal Demarcation Board 2016; Zulu 2014). Municipalities are responsible for the provision of basic services (Zulu 2014). Metropolitan municipalities have exclusive executive and legislative authority in their area, while local and district municipalities share the authority (Municipal Demarcation Board 2016).

Municipalities have been lagging in the implementation of IFMIS (Nabe 2016; Zulu 2014). Most research on IFMIS mainly focuses on national and provincial government

TABLE 1: Types of municipalities in South Africa.

\begin{tabular}{ll}
\hline Municipality type & Explanation \\
\hline $\begin{array}{l}\text { Metropolitan } \\
\text { municipalities }\end{array}$ & $\begin{array}{l}\text { These exist in the six biggest cities in South Africa. The } \\
\text { country consists of eight metropolitan municipalities. }\end{array}$ \\
& $\begin{array}{l}\text { Metropolitan municipalities have charasteristic that include: } \\
\text { (1) areas of high population, (2) an intense movement of } \\
\text { people, goods and services and (3) extensive development, } \\
\text { and multiple business district and industrial areas Invalid } \\
\text { source specified. }\end{array}$ \\
$\begin{array}{ll}\text { Local municipalities } \\
\text { (Category B) }\end{array}$ & $\begin{array}{l}\text { These are 226 local municipalities that exist in the area that } \\
\text { falls outside of the six metropolitan areas and are divided } \\
\text { into local municipalities (DPLG 2010; Jacobs, Rivett \& } \\
\text { Chemisto 2018). }\end{array}$ \\
$\begin{array}{l}\text { District municipalities } \\
\text { (Category } C)\end{array}$ & $\begin{array}{l}\text { There are 44 district municipalities in South Africa, usually } \\
\text { between three and six local municipalities that are } \\
\text { demarcated into a district council (Jacobs et al. 2018). }\end{array}$ \\
\hline
\end{tabular}

spheres, and little research has considered the local government sphere (municipalities). Compared to national and provincial government spheres, municipalities are at the bottom of the pyramid (Jacobs et al. 2018). Furthermore, performance of municipalities is usually evaluated and assessed by the top and middle levels, that is, national and provincial government spheres (Jacobs et al. 2018). In addition, government financial management practices in municipalities have been characterised by problems in revenue mobilisation and lack of transparency and accountability in the use of public finance (National Treasury 2018). The problems have previously contributed to persistent increases in budget deficits, public debts and poor performance of the economy, hence the need for the introduction of effective and integrated finance management systems (Nabe 2016). The next section is focused on the type of IFMIS for local government in South Africa.

\section{Integrated Financial Management Information Systems for municipalities in South Africa}

Integrated Financial Management Information Systems for municipalities in South Africa are regarded as one of the most common financial management reform practices, aimed at the promotion of efficiency, effectiveness, accountability, transparency, security of data management and comprehensive financial reporting (Harelimana 2017; Hendricks 2012; Kiarie \& Wanyoike 2016; Micheni 2017). However, there has been limited research focusing on IFMIS for municipalities; most of the studies in the literature were focused on national and provincial government departments (Harelimana 2017; Micheni 2017; Njonde \& Kimanzi 2014). This introduction of IFMIS is based on the mSCOA which states that IFMIS in municipalities should be implemented based on the mSCOA chart (National Treasury 2018). The mSCOA chart illustrated in Figure 1 was regulated in 2014 when the National Treasury commissioned a study into the financial management and internal control systems used at municipalities. The mSCOA chart requires a significant change in all municipalities' business processes and requires the modernisation of financial management in the country. The mSCOA chart can be regarded as a classification framework for financial management, which aims to improve data quality and integrity through requiring the classification of transactions consistently across municipalities and from one financial year to the next.

A key design principle of the mSCOA chart for IFMIS is the enabling of a central point of access of all municipalities information in the country for usage (National Treasury 2018). This is achieved by reporting to various stakeholders at provincial and national levels and the ability to assess municipalities' performance against strategic planning and outcomes-based objectives of the Republic of South Africa. In ensuring successful financial management, all municipalities were required to implement their IFMIS based on the mSCOA chart requirement and all municipalities are further required to prepare and approve 


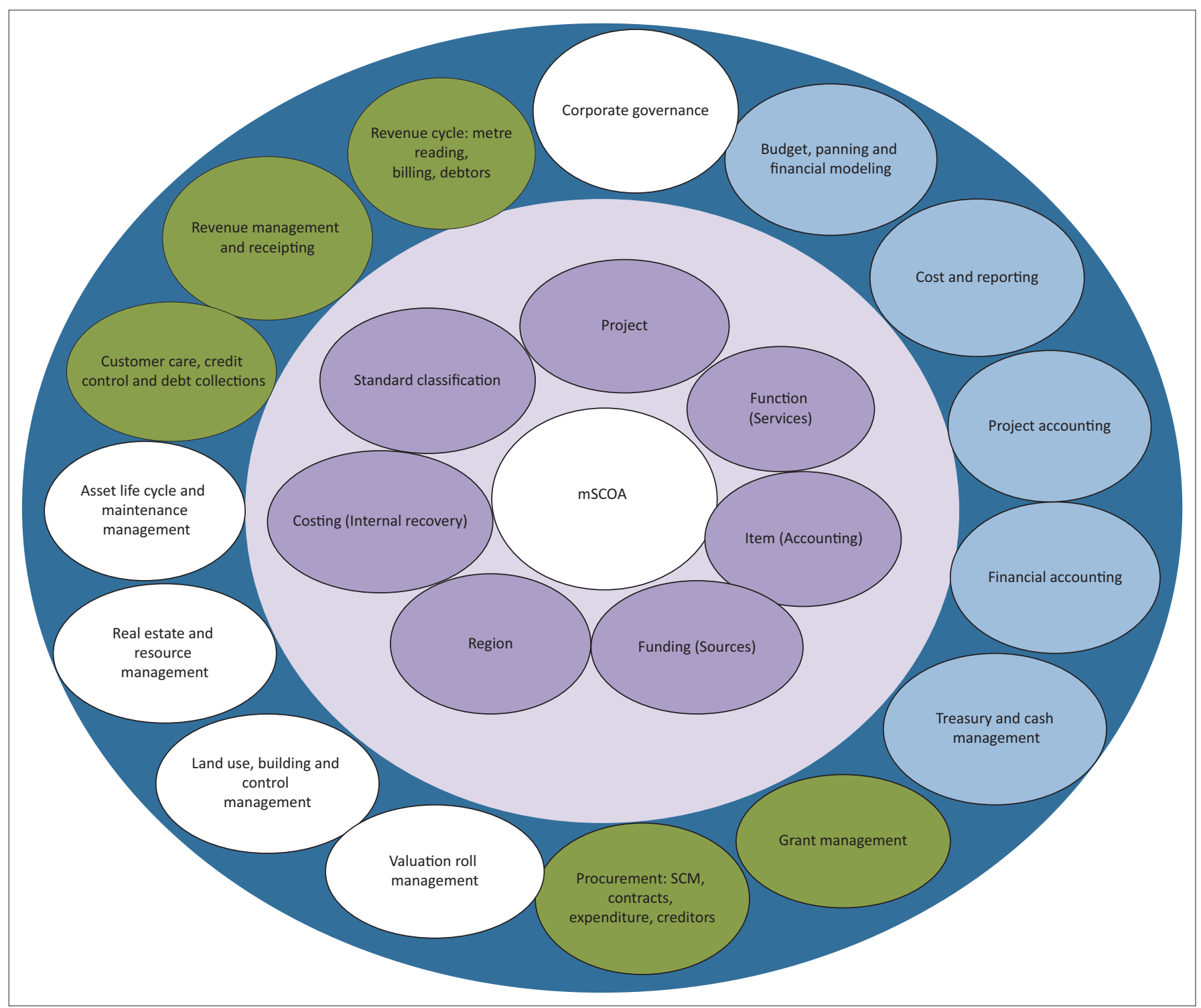

Source: National Treasury, 2018, Function segment of mSCOA, Republic of South Africa, Cape Town.

FIGURE 1: The Municipal Regulations on a Standard Chart of Accounts chart for local government sphere

a fully mSCOA-compliant budget cycle (National Treasury 2018). The end-users of the IFIMS are usually employees who are responsible to process financial transactions such as budget preparation, budget executions to accounting and reporting in municipalities. Even though some of the municipalities have implemented IFMIS, there is still resistance from some municipalities to implement IFMIS (National Treasury 2018).

\section{Resistance to change in the implementation of new technology in organisations}

Organisations are constantly required to adapt to changing environments to be suitable and competitive (Hornstein 2015). Municipalities compared to national and provincial government spheres are currently facing numerous challenges that force them to change as they have introduced IS to perform their financial management (Lodge 2005; Zulu 2014). Innovations that involve technology advancements usually require major changes for individuals or employees in organisations (Eason 2014). Previous research mentions that the implementation of new ways in the workplace requires people to explore previously unknown ways of working and to adopt them as their new standards (Hornstein 2015). As this study is focused on the intersection of municipalities and the change management, the study uses the definition of change management as the process of assisting employees and public sector in passing from an old way of doing things to a new way of doing things' (Lorenzi \& Riley 2003). Change management is the creation, maintaining and systematic evaluation of changes in an organisation whether it is public or private (Nabe 2016; Pasquini et al. 2015).

Hornstein (2015) notes that it does not come easily to employees to adapt to change; they need to be supported by deliberate change management. This is even truer to government departments because they have a number of specific complicating characteristics, including a wide-range 
of roles, responsibilities and disciplines, the legislation and regulations involved and the costs in the case of failure (Zulu 2014). Resistance to change is seen as one of the main causes of change not 'sticking' (Kotter 1995; Talke \& Heidenreich 2014). Resistance to change can be reduced by enhancing readiness for change (Eason 2014; Hornstein 2015). Holt et al. (2007). Kahari, Gathogo and Wanyoike (2015) point out that four factors influence the individual readiness for change: (1) the capability to bring about this change (self-efficacy and sense of ownership), (2) the commitment of leaders (management support), (3) the correctness of the change for the organisation (appropriateness) and (4) the importance of the change if beneficial to the business processes or work activities (personal valence).

In the context of end-users of IS, change management can be described as the strategy to ensure that end-users adopt the newly introduced system or software (Eason 2014). The introduction of a new or integrating existing system such as IFMIS fundamentally changes the way operations are carried out in municipalities and, therefore, requires a carefully managed process to avert probable end-users' resistance (Kahari et al. 2015).

\section{Theoretical background}

Theory of change management as proposed by Kotter (1995) is chosen as an appropriate theoretical framework as theoretical background for this study. The theory focuses on people's traits as a method for realising lasting changes in organisations (Martinsou \& Hoverfalt 2018). At its inception, this theory has become a baseline model in the area of organisational change management enhancement (Rosenbaum, More \& Steane 2018). Theory has also been applied and tested in a variety of settings of change management, including health care (Balje, Carter \& Velthuijsen 2015), criminal justice (King et al. 2017), education (Watts, Cuellar \& O'Sillivan 2008) and small and mediumsized enterprises (SMEs) (Nikolaos, George \& Apostolos 2016). This justifies why this theoretical framework was used in the context of this study.

The theory consists of an eight-step model, as illustrated in Figure 2. All eight steps need to be addressed or else it will be difficult to realise change in an organisation context (Martinsou \& Hoverfalt 2018). The steps illustrate that to understand change, there must also be a brief understanding of the states that an organisation must pass through to realise change, that is, 'To move from the present to a desirable future state' (Happelbalum, Malo \& Shafiq 2012).

The eight steps illustrated in Figure 2 can be categorised into three different phases that are based on Lewin's (1947) views of organisational change management (Balje et al. 2015; Mourfield 2014). The three stages for realising change are: unfreezing, change and refreezing, as illustrated in Figure 3. These are discussed based on the eight steps.

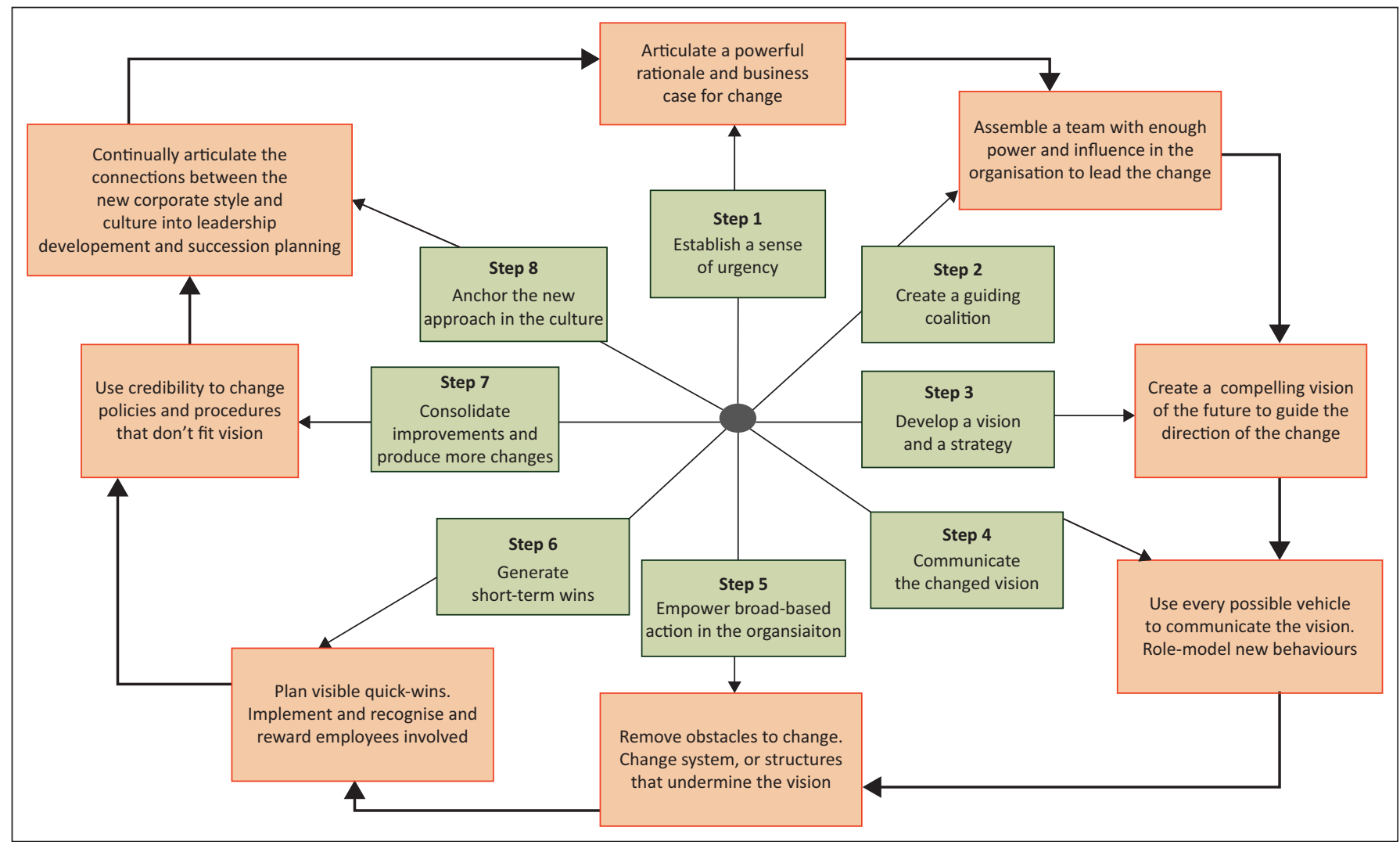

Source: Adapted from Kotter, J., 1995, 'Leading change: Why transformation efforts fail?', Harvard Business Review 73(2), $59-67$.

FIGURE 2: Eight-step model for managing change. 


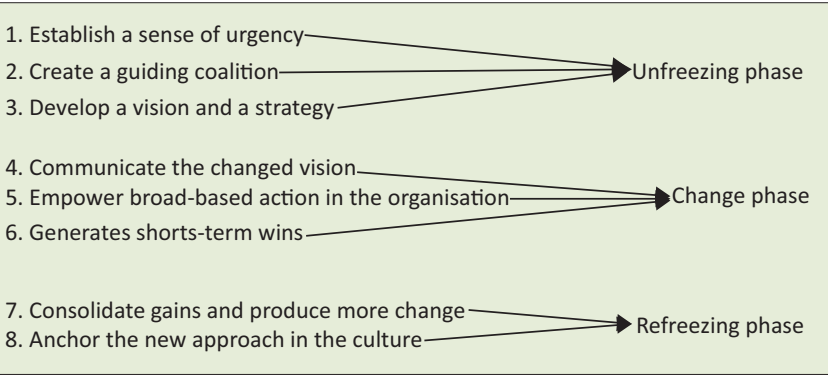

Source: Adapted from Lewins, K., 1947, 'Frontiers in group dynamics: Concepts, method and reality in social science, social equilibria and social change', Human Relations 1(1), 5-41. https://doi.org/10.1177/001872674700100103

FIGURE 3: Three-stage model for managing change.

\section{Phase 1: Unfreezing}

The unfreezing phase recognises the need to discard old behaviour, structures, processes and culture before successfully adopting new approaches (Balje et al. 2015). The phase embraces the first three steps by Balje et al. (2015) and Kotter (1995). This phase is about breaking down the existing 'status quo', for instance, through developing a compelling message, establishing a sense of urgency among employees, persuading stakeholders and forming a powerful coalition to ensure support and commitment to changes (Nikolaos et al. 2016).

One of the most common ways to overcome resistance to change is to inform people beforehand about the IS that will be implemented (Kotter 1995). End-users need first to be convinced that change is necessary (Balje et al. 2015). This phase is about releasing the present state that may involve quite different problems in different organisations. Furthermore, to break open the sense of security and selfrighteousness, it is often necessary to bring about an emotional stir-up (Lewins 1947). The most difficult temptation to avoid is pushing the implementation stage too early. Most organisations make this mistake and end up experiencing resistance to change (King et al. 2017; Watts et al. 2008). Furthermore, by passing the early unfreezing stage, the change becomes purely cosmetic and expensive in the end, because it means that everything has to be repeated properly, after implementation (Balje et al. 2015; Mourfield 2014).

\section{Phase 2: Change}

The change phase is when it is assumed that employees within the organisation need to begin to resolve their uncertainties and look for ways to adapt to the identified change. Three steps (4-6) from Kotter's (1995) change management model are included in this stage. This is because, at the onset of change, there may be many great ideas and solutions floating around, more especially by end-users (Balje et al. 2015; Nikolaos et al. 2016). In this regard, the three steps are important for this stage because they include setting clear objectives and challenging targets, empowering action, involving people (including end-users) and using training, coaching and role models that can help make the transition successful (Balje et al. 2015; Watts et al. 2008). As employees adapt, mistakes should be both accepted and expected during this phase. Business changes are not smooth, natural transitions, but periods of considerable confusion and unnatural activity, which require careful and skilful managing and better strategies (Balje et al. 2015; Mourfield 2014).

\section{Phase 3: Refreezing}

The refreezing phase incorporates the two last steps (7 and 8) in Kotter's (1995) change management model. These steps posit that organisations need to note that many change projects fail because they declare victory too early (Kotter 1995). In addition, real change runs deep, so they need to note that quick wins are only the beginning of what needs to be performed to achieve long-term change. Hence, organisations need to anchor changes in a corporate culture. In addition, they should ensure that changes become part of the core business of an organisation to make any change stick. Continuous efforts should be made to ensure that the change is seen in every aspect of the organisation (Nikolaos et al. 2016). Without reinforcement, change could be shortlived (Lewins 1947). Nevertheless, organisations need to reinforce continually and institutionalise the change by a variety of means (King et al. 2017; Nikolaos et al. 2016). This can assist them to prevent individuals and and groups resisting change.

In the context of IS implementation, by effective communication, the end-users form realistic expectations for the implemented system; thus, there is a good chance of uncertainties being reduced (Balje et al. 2015). This phase also encourages communication which, in turn, also encourages teamwork (Lewins 1947). However, communication must be focused rather than ignored and timing is important for communication (Mourfield 2014). Communication is vital in change management and the facilitating project team should be focused, committed and motivated to support end-users both during and after the implementation of the project (system) (Balje et al. 2015).

\section{Research methodology}

The study employed a qualitative research approach and the study was based on the interpretivist paradigm where the reality is viewed as socially constructed (Collis \& Hussey 2009). The researchers were aware of the fact that studying factors that affect change management in the implementation of IFMIS in municipalities requires an in-depth understanding of the context of the individuals (end-users) who are affected. Hence, it was necessary to adopt a qualitative case study strategy. A case study was used in this study because it is focused on the interaction between end-users and technology.

\section{Sample and data collection}

Semi-structured interviews were conducted by using intended end-users of IFMIS, such as IFMIS within the Western Cape municipalities. Respondents were employees who are required to use IFMIS for financial management 
processes for budget preparation and the executions (such as commitment control, cash or debt management and treasury operations), as well as for accounting and reporting. Four municipalities were selected in the Western Cape and the sample of end-users consisted of three employees in each municipality. In total, 16 end-users were interviewed in the five Western Cape local governments. The interviews were focused on the experience of the implementation of IFMIS, system use and change management for the implementation. The data were collected from April until June 2018.

Many of the findings presented here were derived as a result of open discussions generated by the questions. To complement open-ended interviews, the researchers gathered and reviewed key municipal documents and documents in the national treasury website about the IFMIS for municipalities. These included integrated development plans (plans for a municipality that give an overall framework for development), and spatial development frameworks (which set out the 'spatial vision' for the municipality). The researchers also examined other relevant information where it was available, such as municipal websites and a variety of documents supplied by respondents.

\section{Data analysis}

The qualitative thematic analysis (Fereday \& MuirCochrane 2008) was used to analyse the data in a deductive manner. The deductive thematic analysis was used because it is regarded as a good data analysis technique that can be used to report on the factors affecting change management in the implementation of IFMIS in local government departments in the Western Cape. The researchers used Lewins's (1947) three-stage model of change management: (1) unfreeze, (2) change and (3) refreeze as primary codes in the analysis. The researchers furthermore used the eightstep model of change management by Kotter (1995) to provide sub-categories in each code, as explained in the theoretical background section. This process helped to identify factors affecting post-implmentation of IFMIS in municipalities.

\section{Case description: The Western Cape}

The Western Cape province was selected for this research because it is the only province that is currently focusing on the implementation of IFMIS in municipalities (National Treasury 2018). The Western Cape province is divided for local government purposes into a metropolitan municipality (Category A), district (Category B) and local (category C), as shown in Table 2.

Four municipalities form the focus of this research study, and they are: (1) two municipalities under category B and (2) two municipalities under category $C$, which are under the selected two in category B. The description of the selected municipalities is illustrated in Table 2. All the chosen municipalities have implemented IFMIS and are involved in financial management processes for budget preparation and executions, as well as accounting and reporting.

\section{Ethical consideration}

This article presents a part of the findings from the doctoral study registered at the University of Cape Town (UCT). The doctoral research was approved by the university ethics committee. I was also granted approval to conduct data collection within municipalities of the Western Cape. The respondents were only interviewed after they had given me their informed consent. The respondents were informed that their participation in the study was voluntary and could be withdrawn at any time. The identities of the respondents in the study were anonymised.

\section{Research findings and discussion}

The data collected show that the implementation of IS such as IFMIS in municipalities was a top-down implementation, which was only limited to specific stakeholders and is discussed in the following section. Furthermore, the data collection shows that the implementation of IFMIS in municipalities is not a smooth process, and there are

TABLE 2: Description of municipalities participated in the study.

\begin{tabular}{|c|c|c|c|c|c|c|c|c|}
\hline \multirow[t]{2}{*}{ Description } & \multirow{2}{*}{$\begin{array}{c}\text { District } \\
\text { municipality A }\end{array}$} & \multirow{2}{*}{$\begin{array}{c}\text { District } \\
\text { municipality B }\end{array}$} & \multirow{2}{*}{$\begin{array}{c}\text { Local } \\
\text { municipality C }\end{array}$} & \multirow{2}{*}{$\begin{array}{c}\text { Local } \\
\text { municipality D }\end{array}$} & \multicolumn{4}{|c|}{ Service delivery role } \\
\hline & & & & & $\begin{array}{c}\text { Coordinate local } \\
\text { municipalities }\end{array}$ & $\begin{array}{c}\text { Coordinate local } \\
\text { municipalities }\end{array}$ & $\begin{array}{l}\text { Provide services } \\
\text { to citizens }\end{array}$ & $\begin{array}{c}\text { Provide services } \\
\text { to citizens }\end{array}$ \\
\hline Population (\%) & 787485 & 391766 & 115727 & 113761 & - & - & - & - \\
\hline Demographics & & & & & - & - & - & - \\
\hline Black people (\%) & 24.4 & 15.1 & 15.1 & 52.5 & - & - & - & - \\
\hline Mixed-race people (\%) & 67.8 & 69 & 69 & 41.3 & - & - & - & - \\
\hline White people (\%) & 7.7 & 15.6 & 15.6 & 6.2 & - & - & - & - \\
\hline Indian or Asian people (\%) & 0.1 & 0.3 & 0.3 & 0.0004 & - & - & - & - \\
\hline Dwellings & & & & & - & - & - & - \\
\hline Formal (\%) & - & - & - & - & 79 & 81.9 & 59.1 & 88.5 \\
\hline Informal (\%) & - & - & - & - & 21 & 18.1 & 40.9 & 11.5 \\
\hline \multicolumn{9}{|l|}{ Languages } \\
\hline Afrikaans (\%) & - & - & - & - & 73.5 & 75.8 & 44.9 & 79.3 \\
\hline English (\%) & - & - & - & - & 2.5 & 3 & 3.6 & 4.5 \\
\hline \multicolumn{9}{|l|}{ Education } \\
\hline Matric (\%) & - & - & - & - & 19.1 & 19.5 & 19.5 & 20.8 \\
\hline Higher education (\%) & - & - & - & - & 3.3 & 3.8 & 4.8 & 5 \\
\hline
\end{tabular}

Source: Adapted from Statistics South Africa (STATS SA), 2011, Municipalites in the Western Cape, viewed n.d., from https://www.statssa.gov.za/:8282/webview/. 


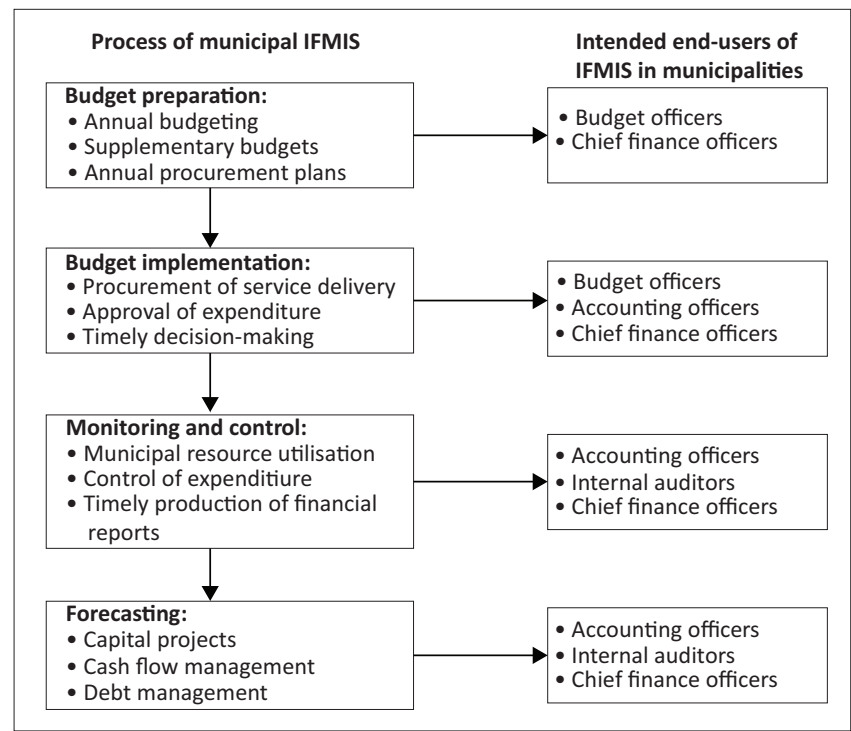

FIGURE 4: The roles of end-users of Integrated Financial Management Information Systems in municipalities.

challenges involved that were mentioned by the end-users of IFMIS in municipalities in the Western Cape. The intended end-users of IFMIS include budget officers, accounting officers, internal auditors and chief finance officers in municipalities (National Treasury 2018). These are the employees responsible to process financial transactions such as budget preparation, budget executions to accounting, monitoring and control and forecasting the flow of financial management in the Provincial Treasury of the Western Cape of 2018, as illustrated in Figure 4.

As municipalities are grappling with the implementation of IFMIS (Nabe 2016), other municipalities that have implemented IFMIS are still struggling with poor use and acceptance because of the dissatisfaction of end-users with the introduced systems so that they require reimplementation. The interviewed end-users in the study, who included four end-users in each municipalities, that is, two district municipalities and two local municipalities in the Western Cape, believe that their needs as employees were not adequately met. They expressed dissatisfaction with the usability of the system and lack of specific functions. Some end-users reported that sometimes, they were not able to meet their deadlines. These challenges in the implementation of IFMIS are discussed in the following sections based on the theoretical framework adopted for this study.

\section{Unfreezing phase: Sense of urgency, guiding coalition and vision and strategy for change}

The unfreeze phase is meant to involve a process of raising awareness in employees who will be affected by the change; however, this was not followed in the implementation of the IFMIS. Instead, end-users of IFMIS were introduced to the system after the system was already developed.

\section{Lack of awareness}

End-users lacked awareness of the results or the reasons for the need of an integrated financial management system or of implementing new systems for financial management.
Most end-users were happy or satisfied with the newly introduced IFMIS:

'Other people do not use these financial systems lack knowledge of the system and rely on vendors' assistance and that is the challenge that we are currently facing. The other system that we were using was much better.' (Accounting Officer in Local Municipality A)

Other challenges explained by the respondents include strategic planning, internal and external policies and leadership issues of the implementation project at the beginning of the project. Change management is a vital factor that affects the climate and outcomes of project implementation. The importance of change management is the achievement of technology implementation in any organisation and is usually based on the degree of strategic planning of organisational requirements and objectives (Nikolaos et al. 2016; Thilo et al. 2017).

\section{Communication with end-users in strategic planning for the development of Integrated Financial Management Information Systems}

The aim of engaging with end-users of IFMIS in the planning phase of the development was to determine whether endusers know what led to the decision to the development of IFMIS in their municipalities. End-users in selected municipalities were asked whether the shared vision of the development of IFMIS was established in their municipalities or it was performed by the provincial treasury. Although the documents on the website of national treasury mention that end-users of IFMIS have awareness of why the development took place, the responses of end-users from all the municipalities engaged, show that they do not really have knowledge of the vision of the IFMIS development. End-users only knew that the current ways of their financial management change but did not have knowledge of how this will be performed:

'Most of the information was received via the communication emails; but there was no formal communication to the end-users ... We were briefed that we'll change to new financial systems that will be implemented ... The top management [Provincial Treasury] attended meetings for this and All I know is that we were told that new financial systems will be implemented ... The information we got was that we are migrating from this financial system to the new one; but no vision was shared formally.' (Budget Officer and Accounting Officer from District Municipality B)

In addition, other end-users mentioned that the communication was a problem, as they were not formally informed of the milestones in the IFMIS project.

'Communication during the project was very poor from the project team ... They only communicated with us when we were about the receive training of the system ... There was no formal communication coming from either the project management, nor from top management .... I only read some of the documents.' (Chief Finance Officer from District Municipality A)

This finding is in alignment with (Donoso et al. 2014) findings which state that if the end user of the implemented product or service perceives the decision-making process as unfair, then that will lead to the distrusting the organisation, even with a favourable change result. 


\section{Change phase: Change vision, empowerment and short-term wins}

\section{Top-down development process of Integrated Financia Management Information Systems}

The findings show that the implementation of IFMIS followed top-down implementation that is a linear process where the financial systems were implemented and then introduced to the employees afterwards. The IFMIS were implemented by external vendors who specialise in developing IS for organisations in South Africa. The vendors implemented the systems without engagement with end-users; they communicated with top management (provincial treasury and national treasury). This means that systems were implemented with the involvement of provincial treasury and external vendors who were appointed by the provincial treasury and there was no involvement of employees who will be directly affected by the change. The development of IFMIS for municipalities was focused on management awareness at a broader administrative and council level, and there was nothing said about actual end-users in the planning.

The role of the provincial treasury in the implementation of IFMIS for municipalities was to ensure that implementation of IFMIS takes place and that it is in-line with the mSCOA chart, which outlines the financial management mandate for municipalities in South Africa. Workers were asked about the ways in which IFMIS were developed in municipalities in the Western Cape, and one interviewee explained:

'IFMIS are implemented based on the mSCOA as it is a business reform for financial management in all municipalities. Many end-users don't know much about the mSCOA because usually, it is us who are responsible for the mSCOA and usually mSCOA run in the background of these IFMIS. These IFMIS are implemented by appointed vendors and these systems are basically Enterprise Resource Planning (ERP) systems and endusers have access to them based on their roles and responsibilities when the system is already implemented.' (Provincial Treasury of the Western Cape)

\section{Prioritisation of stakeholders for the development of Integrated Financial Management Information Systems}

The involvement and prioritisation of stakeholders in the development of IFMIS was not unfavourable for end-users

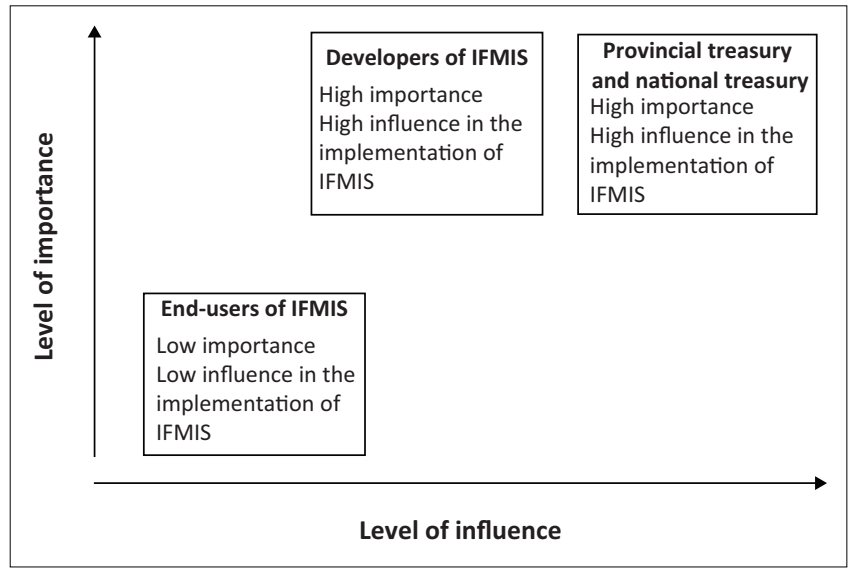

FIGURE 5: Prioritisation of stakeholders in the development of the Integrated Financial Management Information Systems for municipalities. of IFMIS as their level of importance and influence was very low compared to external stakeholders such as national and provincial and national treasury (Document 86 in Treasury Website), and this is depicted in Figure 5. Stakeholders who were involved in the implementation got rid of the old ways of financial management and existed systems in municipalities and end-users were transferred to the newly implemented IS for financial management. In addition, findings from Document 86 in the National Treasury Website provided the stakeholder identification and prioritisation in the system development in municipalities. This was presented in a form of portfolio planning, key milestones and activities of the project plan of the IFMIS which revealed that the main important stakeholders for the development project included national and provincial treasury, and external vendors were regarded as important stakeholders and decision-makers in the development processes of IFMIS for municipalities, as illustrated in Figure 5.

In the project milestones and activities for the project life cycle, there were not even one joint application design (JAD) session that can be used to allow end-users to identify the business and system requirements that they believe would be useful for work processes that directly affect them. Instead, end-users were only listed to be involved during testing and training once the system is ready for use. The project manager who is based at the Provincial Treasury of the Western Cape was interviewed about how they handled preimplementation, implementation and post-implementation of the system:

'We followed on a big-bang implementation style of the financial systems, hired external vendors to develop packages and we trained intended users in municipalities on everything. That did not work, and we had to go back and implement one module at a time and roll out the system per unit and department still there is still a problem of resistance and other systems are to be re-implemented.' (Provincial Treasury of the Western Cape)

\section{Lack of end user involvement in the implementation stages}

The end-users of IFMIS were not involved in the implementation of the systems. All end-users in local government are educated; some of them had university degrees, diplomas, honours and some had master's degree qualifications. Further, some of the respondents (end-users) had a good understanding and prior knowledge of what information system implementation entails; some of them had performed a course which focused on the implementation of IS during their studies:

'I was once involved in systems development, but it was not a systems development of the system that I use at work, that was years back while I was still doing my undergraduate degree.' (Chief Finance Officer in District Municipality B)

This shows that end-users had the potential to engage in an information system implementation process.

Some end-users did not have knowledge about system implementation. However, they showed interest and believed 
that they should be involved in the implementation of systems that affect their work processes because they understood the work process better than the developers. When asked whether they would advise employees to be involved in the implementation of IS that they would use, the majority of end-users said:

'Yes, I would advise employees including myself to take part in system development and decision-making of systems that affect their work processes because I think this has a great potential to assist people to have a better understanding of what is going on behind closed-doors of the implementation.' (Budget Officer in Local Municipality A)

\section{Refreeze phase: Consolidate gains and produce more change, and anchor new approaches in the culture}

\section{Training of end-users before using the system}

End-users were asked about post-implementation and training questions regarding IFMIS. This was to determine whether more training and strategies are required. One end-user from municipality A mentioned that resources were shared between testing and training; therefore, training had to be sacrificed. Even though training was provided to end-users, they could not understand why some of the functions of the system were there and as a result, $70 \%$ out of those 16 end-users engaged were not satisfied with the newly introduced IFMIS:

\begin{abstract}
'Other people [intended end-users] do not use these financial systems lack knowledges of the system and rely on vendors' assistance and that is the challenge that we are currently facing. The previous system and the way we used to do our financial reporting was much better. These are totally different from the way we work, and I so wish they looked at our previous systems before coming up with something totally different.' (Budget Officer in Local Municipality B)
\end{abstract}

In addition, end-users mentioned that the training was not accommodating to them as they were not familiar with the system. The end-user further added: 'yes during the training I did made a comment to the project team that I will not use this because these functionalities are frustrating'. They further mentioned that they were not happy with the way the system was introduced to them after implementation because they did not get the confidence that they were looking for in terms of using the system on their own. This shows that endusers would like to receive more training as this would enable them to better understand the systems for their financial management activities, even though these were given after implementation, which pointed out:

\footnotetext{
'We did not understand what we were trained on, as the system was not aligned to our usual business process. More communication was required to get buy-in from us employees who will be the end-users of the system, and ensuring the questions are adequately and timeously answered to avoid any suspicion.' (Accounting Officer in Local Municipality A)
}

These findings concede that it is easy for end-users to forget how to use the system; however, having a clear change stage involves setting clear objectives and challenging targets, empowering action, involving people (including end-users) and using training, coaching and role models who can help make the transition successful. Involving end-users in the development stages may contribute to new ways of doing tasks, while it challenges people to develop new skills (Thilo et al. 2017).

\section{Complexities in using implemented Integrated Financial Management Information Systems}

The findings show that end-users were not quite satisfied with the functionalities in the implemented IFMIS. Multiple participants from different municipalities expressed dissatisfaction with the user-friendliness of the system and lack of specific functions. Some end-users reported that sometimes, they were not able to meet their deadlines:

'I do meet my deadlines but sometimes ... if it's a teamwork its sometimes challenging to meet deadlines as other people often hesitate to do their tasks on the system ... sometimes it's challenging to meet deadlines as I'd be required to ... assist them with their tasks.' (Chief Finance Officer in District Municipality B)

The respondents believed that their needs as employees were not adequately met. Furthermore, end-users mentioned that, with the implemented IFMIS, there were so many uncertainties involved. This finding calls for a re-examination of the functionalities of IFMIS for local government. There seems to be a challenge of poor identification with system requirements. The vendors who implemented the systems might have failed to understand the specific needs of local municipalities. This challenge could have been averted by involving end-users during the design and implementation of the system.

Furthermore, the implementation of IFMIS might require 'system re-implementation' for some end-users who are struggling with the use of the system. This is because the implementation of these financial systems and conversion solutions was explored by the Treasury in consultation with the system vendors. It should be noted that there was no user involvement in the implementation of IFMIS. It is reported that there are systems currently in use in some municipalities, and these municipalities might not agree to accommodate IFMIS segments nor will it be cost-effective to upgrade and reconfigure.

\section{Conclusion}

The study sought to investigate factors and challenges affecting post-implementation regarding the use and acceptance of IFMIS in municipalities. This research found that the development of IFMIS in municipalities did not consider the overall process of change management to achieve successful implementation of IFMIS had mainly focused on the success of the system with little consideration of end-users' needs, hence resistance to change are encountered. This research found that whenever implementing change, the human element must be acknowledged, and that resistance is inevitable. Employees 
need to be a part of the implementation process and they need to be heard, because people are more likely to accept the forthcoming change if they know what to expect in each phase of the project. This study argues that one way of improving change management is to involve end-users in the design and development of the system that will affect their work processes. This article reiterates the importance of end-users being involved in all the stages of the implementation, so that system requirements would have been met (Bennis 2015). Not involving employees in making decisions that affect their work processes may create a fear of the unknown (Holgersson 2014). This relates to uncertainty and lack of trust about the outcomes of implementation. Furthermore, to a large extent, system implementation at local government has mainly focused on the success of the system implemented, not on the impact the change has had on employees.

\section{Acknowledgements Competing interests}

The authors declare that they have no financial or personal relationship(s) that may have inappropriately influenced them in writing this article.

\section{Author's contributions}

N.G. is the first author of this research article and it is a publication extracted from a $\mathrm{PhD}$ degree (in progress). W.C. is my $\mathrm{PhD}$ supervisor and gave constructive feedback, suggestions, guidance and direction in making sure that this research article is complete and he made valuable contribution; hence, he is the second author to the article. Both authors contributed in the write-up of the research article.

\section{Funding information}

I would like to extend my gratitude to the National Research Foundation (NRF) for the support to my PhD research.

\section{Data availability statement}

Data sharing is not applicable to this article as no new data were created or analysed in this study.

\section{Disclaimer}

The views and opinions expressed in this article are those of the authors and do not necessarily reflect the official policy or position of any affiliated agency of the authors.

\section{References}

Balje, J., Carter, A. \& Velthuijsen, H., 2015, 'Agile development as a change management approach in health care innovation projects', 3rd Understanding Small Enterprises (USE) Conference 2015, Hanze University of Applied Sciences, Groningen, The Netherlands, October 21-23, pp. 1-16.

Bennis, A., 2015, A contextual co-design approach to promote acceptance of new supervisory technology among healthcare professionals, University of Twente, Enschede.
Chado, H., 2015, The effects of IFMIS on financial management public sector in Kenya, University of Nairobi, Nairobi, Kenya.

Collis, J. \& Hussey, R., 2009, Business research: A practical guide for undergraduate and postgraduate students, Palgrave, Macmillan.

Da Cruz, N., Tavares, A., Marques, R., Jorge, S. \& De Sousa, L., 2016, 'Measuring local government transparency', Public Management Review 18(6), 866-893. https:// doi.org/10.1080/14719037.2015.1051572

Donoso, V., Van Mechelen, M. \& Verdoodt, V., 2014, Increasing user empowerment through participatory and co-design methodologies, EMSOC, Brussels.

DPLG, 2010, Policy process on the system of provincial and local government Background, policy questions, processes and participation, Department of Provincial and Local Government, Pretoria.

Eason, K., 2014, Technology transformation and organisational change, CRC Press, London.

Fereday, J. \& Muir-Cochrane, E., 2008, 'Demonstrating rigor using thematic analysis: An hybrid approach of inductive and deductive coding', International Journal of Qualitative Methods 5(1), 80-92. https://doi.org/10.1177/160940690600500107

Happelbalum, S., Malo, J. \& Shafiq, H., 2012, 'Back to the future: Revisiting Kotter's (1995) change model', Journal of Management Development 31(8), 764-784. https://doi.org/10.1108/02621711211253231

Harelimana, J., 2017, 'Impact of integrated financial management information systems on performance of public institutions in Rwanda', Enterprise Risk Management 3(1), 38-51. https://doi.org/10.5296/erm.v3il.12230

Hendricks, C., 2012, 'Integrated Financial Management Information systems: Guidelines for effective implementation by public sector in South Africa', South African Journal of Information Systems 14(1), 1-9. https://doi.org/10.4102/sajim. v14i1.529

Holgersson, J., 2014, User participation in public e-service development, University of Skovde, Sweden.

Holt, D., Armenakis, A., Field, H. \& Harries, S., 2007, 'Readiness for organisational change: The systematic development of scale', Journal of Applied Behavioural Science 43(2), 232-255. https://doi.org/10.1177/0021886306295295

Hornstein, H., 2015, 'The integration of project management and organisational change management is now a necessity', International Journal of Project Management 33, 291-298. https://doi.org/10.1016/j.ijproman.2014.08.005

Jacobs, C., Rivett, U. \& Chemisto, M., 2018, 'Developing capacity through co-designing: The case of two municipalities in rural South Africa', Information and Technology Development 25(2), 204-226. https://doi.org/10.1080/02681102.2018.14704788

Kahari, C.K., Gathogo, G. \& Wanyoike, D., 2015, 'Assessment of factors affecting the implementation of Integrated Financial Management Information Systems in the country governments: A case of Nyandama country, Kenya', International Journal of Economics, Commerce and Management 3(11), 1352-1373.

Kiarie, A. \& Wanyoike, D., 2016, 'Determinants of successful implementation of government-funded projects in Kenya: A case study of Integrated Financial Management Information Systems (IFMIS)', International Journal of Innovation and Research 5(10), 169-175.

King, S., Hogkins, M. \& Cornish, N., 2017, 'Can models of organisational change help to understand "success and failure" in community sentence? Applying Kotter's model of organisational change to an intended offender management case study', Criminology and Criminal Justice 18(3), 273-290. https://doi. org/10.1177/1748895817721274

Kotter, J., 1995, 'Leading change: Why transformation efforts fail?', Harvard Business Review 73(2), 59-67.

Lewins, K., 1947, 'Frontiers in group dynamics: Concepts, method and reality in social science, social equilibria and social change', Human Relations 1(1), 5-41. https:// doi.org/10.1177/001872674700100103

Lodge, T., 2005, 'Provincial government and state authority in South Africa', Journal of Southern African Studies 3(194), 737-753. https://doi.org/10.1080/ 03057070500370480

Lorenzi, N. \& Riley, R., 2003, 'Organisational issue-change', International Journal of Medical Informatics 69(3), 197-203. https://doi.org/10.1016/S1386-5056(02)00105-3

Martinsou, M. \& Hoverfalt, P., 2018, 'Change program management: Towards a capability for managing value-oriented, integrated multi-project change in its context', International Journal of Project Management 36, 134-146. https://doi. org/10.1016/j.ijproman.2017.04.018

Micheni, E., 2017, 'Analysis of the critical success factors of integrated financial management information systems in selected Kenyan countries', Journal of Finance and Accounting 5(5), 185-192. https://doi.org/10.11648/j.jfa.20170505.12

Mourfield, R., 2014, Organisational change management, Indiana University, Bloomington, IN.

Municipal Demarcation Board, 2016, Metropolitan Municipality of South Africa, viewed n.d., from http://www.demarcation.org.za/site/shapefiles/

Nabe, T., 2016, Impediments to meaningful and effective public participation in local government budgeting in the Western Cape, Stellenbosch University, Cape Town.

National Treasury, 2018, Function segment of mSCOA, Republic of South Africa, Cape Town.

Ngoepe, M. \& Ngulube, P., 2016, 'A framework to embed records management into the auditing process in the public sector in South Africa', Information Development 32(4), 890-903. https://doi.org/10.1177/0266666915573037

Nikolaos, B., George, A. \& Apostolos, V., 2016, 'Organisational change management: Delineating employee reaction to change in SMEs located in Magnesia', Academic Journal of Interdisciplinary Studies 5(1), 303-318. 
Njonde, J. \& Kimanzi, K., 2014, 'Effects of Integrated Financial Management Information Systems on performance of public sector: A case of Nairobi country governments', International Journal of Social Sciences and Entrepreneurship 1(12), 913-936.

Pasquini, L., Zierrogel, G., Cowling, R. \& Shearing, C., 2015, 'What enables local governments to mainstream climate change adaptation: Lessons learned from two municipalities case studies in the Western Cape, South Africa', Climate and Development 7(1), 60-70. https://doi.org/10.1080/17565529.2 014.886994

Rosenbaum, D., More, E. \& Steane, P., 2018, 'Planned organisational change management: Forward to the past? An exploratory literature review', Journal of Organisational Change Management 31(2), 268-303. https://doi.org/10.1108/ JOCM-06-2015-0089

Selfano, O., Peninah, A. \& Sarah, C., 2014, 'Integrated Financial Management Information Systems and its effects on cash management in Eldoret West, Kenya', International Journal of Business and Social Science 5(8), 31-37.

Statistics South Africa (STATS SA), 2011, Municipalites in the Western Cape, viewed n.d., from https://www.statssa.gov.za/:8282/webview/.
Sulla, V. \& Zikhali, P., 2018, Overcoming poverty and inequality in South Africa: An assessment of drivers, constraints and opportunities, World Bank, Washington DC.

Talke, K. \& Heidenreich, S., 2014, 'How to overcome pro-change bias: Incorporating passive and active innovation resistance in innovation decision models', Journa of Product Development and Management Association 31(4), 1-14. https://doi. org/10.1111/jpim.12130

Thilo, F., Bilger, S., Schols, J. \& Hahn, S., 2017, 'Involvement of the end-user Exploration of older people's needs and preferences for a wearable fall detection device: A qualitative descriptive study', Patient Preference and Adherence 11, 11-22. https://doi.org/10.2147/PPA.S119177

Watts, R., Cuellar, N. \& O'Sillivan, A., 2008, 'Developing a blueprint for cultural competence education at Penn', Journal of Professional Nursing 136-142. https:// doi.org/10.10.1016/j.profnurs.2008.01.002

Zakaria, W., Rahman, S. \& Elsayed, M., 2011, 'An analysis of task performance outcomes through e-accounting in Malaysia', Journal of Public Administration and outcomes through e-accounting in Malaysia', Journal of Public Ad
Governance 1(2), 124-139. https://doi.org/105296/jpag.vl.2946

Zulu, T., 2014, Cooperative governance in South Africa: A case study of intergovernmental relations in the provision of housing, University of KwaZuluNatal, Pietermaritzburg, South Africa. 